\title{
The Cap of Liberty: Roman slavery, cultural memory, and magic
}

\author{
mushrooms
}

The commonest psychedelic mushroom growing naturally in Britain, psilocybe semilanceata, is known in English as the Liberty Cap. This name, which references an ancient Roman social practice, has caused considerable speculation in modern literature. This article provides a conclusive etymology for how a modern drug acquired this seemingly obscure name.

Of the species of psychedelic mushroom that are native to Britain, by far the most important is the tiny Psilocybe semilanceata. ${ }^{1}$ The mushroom contains a high and predictable concentration of the drug psilocybin, which acts on the serotonin receptors in the brain to produce effects similar to LSD: visions, synaesthesia, distortions of time and space, and 'death of the ego' (Stamets 1996, 142-5; Miller 2014, 52-3). Because of this, and because of the paucity of other native hallucinogenic species, Psilocybe semilanceata is highly prised by British drug users. It grows pervasively in fields and on lawns across the continent during the autumn months, and, with its distinctive spindly stem and 'pixie cap' head, has become a powerful symbol for a psychedelic counterculture, shorthand for ideas of New Age spiritualism, shamanism, legal transgression, and personal discovery and liberation.

Psilocybe semilanceata is rarely known to its users by its scientific name, but rather by its common or folk name: the Liberty Cap. This name is a reference to the fact that the mushroom's cap looks strikingly like the liberty cap (also referred to as the Phrygian bonnet or the bonnet rouge in a French context) that was a potent symbol of both French and American antimonarchical revolution during the eighteenth century. But the 'cap of liberty,' though perhaps best known in the historical context of these 
revolutions is, in origin, not a modern but an ancient symbol, dating to the Roman Republic. In ancient Rome, the hat was given to slaves as a social and legal marker that they had been freed and it thus carried with it an enormous symbolic value as a marker of status. Yet, although all authors who treat the question of the etymology of this mushroom's name seem to agree that it has something to do with the shape of that American and French revolutionary headgear, nowhere can a clear story be found of how it was that this little mushroom came to acquire this name. ${ }^{2}$ This is not necessarily surprising; the folk names for mushrooms are not officially conferred and instead arise from vernacular usage, so that their origins are often mysterious. Yet the question of how a modern drug acquired a name that seems to reference an ancient social practice is one deserving of an answer.

\section{The Roman Context}

The Roman liberty cap was called the pileus (or pilleus) from a Greek root, pilos, simply meaning 'felt' (Yates, 1875, 919-21). ${ }^{3}$ It was a brimless felt cap, akin to a modern skullcap. As an item of clothing it has an obvious appeal, being exceedingly simple to make, and it was clearly a common item of headwear throughout both Greek and Roman antiquity. Clothing is never simply a physical object, however, and always communicates ideas about the people who wear it (and the people who view it). Never is this truer than of the pileus which had, for the Romans, a very clear symbolic importance. As has been said, the cap was given to a slave as part of the ceremony of his manumission as a marker that he was now free (Persius, Saturae 5.82; Plautus, Amphitryon, 1.1.459-61; Tertullian, de Spectaculis 21; Buckland 1908, 447 and 448-9; 
Edmondson 2008, 30). This was not merely a decorative custom, but possessed the force of law. Legal codes recognised that, in the presence of witnesses, freedom might be granted 'by the giving of the cap' (impostione pilei: Codex Justinianus 8.2.10). The wearing of the pileus, therefore, marked a man out as a freedman, and freedmen were expected to wear the hat on certain ceremonial occasions, in particular the funeral of their former master (Tang 2005, 53). During the Saturnalia, the great winter festival that eventually became our Christmas season, slaves were also permitted to wear the pileus and to speak openly to their masters (Ramsay 1875, 1009). In Petronius' Satyricon, the narrator, Encolpius, is chided at a dinner party for not understanding the hat's significance when a boar is brought into the dining hall wearing a pileus:

\begin{abstract}
Meanwhile, taking a little moment of private thought, I slipped into long musing over why the boar had come out with a liberty cap upon its head. After exhausting every foolish notion I could summon, I resolved to ask my guide about this which so vexed me. 'But even your slave could explain this!' he replied. 'There's no secret, the meaning's clear! This boar, since he was called for in the last course of yesterday's dinner and was dismissed by the guests, today now returns to the party a freedman.' I damned my stupidity and asked nothing more, fearing that I might seem never to have dined among cultured men before (Petronius, Satyricon, 41).
\end{abstract}

To a Roman audience, therefore, the hat was an immediately recognisable symbol, marking its wearer out both as being of low status but also having won the considerable honour of his freedom.

So entwined in Roman thought was the hat and the awarding of freedom that Roman authors began to use the word pileus simply to mean 'freedom.' It appears thus in a wide range of genres, from history (Livy), to biography (Suetonius), to private letters (Seneca), to philosophy (Macrobius), to anecdote (Valerius Maximus). For a Roman, the word pileus meant 'freedom,' every bit as much as it meant 'hat,' and from this usage the Romans derived the phrase servos ad pileum vocare, 'to call the slaves to the cap,' 
meaning to incite a revolt by promising a general manumission of slaves (Livy, 24.32;

Suetonius, Tiberius 4; Seneca, Ep. 47.16; Macrobius, Saturnalia 1.11; Valerius Maximus, 8.6.2).

The pileus was thus a sign of personal liberation from the bondage of slavery. During the late Republic and early Empire, however, this symbol was adopted, in what Mary Nyquist has called 'perhaps the most important early instance of an elite European group's appropriation of the cultural artefacts and rituals of those they exploit or oppress,' as a symbol of political freedom from the tyranny of an unrestrained ruler (Nyquist 2013, 152). It was so used in the wake of the murder of Julius Caesar, in 44 BC. Brutus advertised his part in the deed by striking a now famous coin which, bearing his own bust upon its obverse, on its reverse depicted the pileus between two daggers and above the legend EID MAR, commemorating the fateful day of the murder and proclaiming to all who cared to notice that Rome herself had been freed from slavery (see figure 2). The hat thus began to be conceived as an abstract political symbol and it was to be used repeatedly under the Empire to signify the liberation from tyrannical rule. After Nero's death, Suetonius reports Roman citizens went out into the street, apparently spontaneously, wearing the pileus to celebrate their liberation from Nero's tyranny (Suetonius, Nero 57.1). Numerous subsequent emperors employed the pileus on their coins, often born in the hand of the goddess Liberty. ${ }^{4}$

\section{Rediscovering the Past}

The use of the pileus in the political context marked an important shift in its status as a symbol, ceasing to be an icon of the servile class and being appropriated by the 
Republic's cultural elite. As Empire wound on, however, and painfully yielded itself to kingship, this symbol lost its potency, and so disappeared. Yet it was taken up again in the early modern period, as Europe's new elite began to look to the classical world to help them, amongst other things, to give new symbolic voice to their authority. So it was that the liberty cap began to appear in 'emblem books' that catalogued and explained the symbols of the ancient world, works like Andrea Alciatus's Emblemata (1546), or Cesare Ripa's Iconologia (1593) (at 26 and 292-3 resp.). ${ }^{5}$ The cap again appeared on coins, such as the silver Geuzen Medal, struck in the Netherlands in 1577 to celebrate the retreat of Spanish troops from the country and the signing of the Perpetual Edict. The medal depicted the goddess Liberty holding a wide-brimmed liberty cap beneath the legend VINDICATA LIBERTAS CONCORDIA, 'Liberty and harmony reclaimed' (Holman 1991, 410, n. 46). 6

The British made use of the hat as a symbol of legitimate rule, thanks in part to its transmission via the Dutch; William of Orange, for instance, struck a coin featuring the liberty cap to commemorate his landing in 1688 (Harden 1995, 66-102). Liberty became, for the British, one of the distinctive virtues that made their nation great. Britannia, the nation's personifying goddess, began to be pictured, from the middle of the eighteenth century on, bearing a staff surmounted with the cap of liberty (Higham $2011,31)$. Yet despite such favourable portrayals, the cap found perhaps its most famous expression in British art in William Hogarth's satirical portrait of John Wilkes (Figure 3). Created in 1763, the image showed a seated Wilkes, leering and cross-eyed, with the cap and pole of liberty slung over one shoulder. Drawn after Wilkes had launched open attacks upon the king in Parliament, the image appears to have done little to harm Wilkes' reputation but much to advance the liberty cap to a new role, that of an antimonarchical standard (Maier 1963, 373-95). Less than two years later, in 
America, poles surmounted with the liberty cap were raised in numerous towns to protest the Stamp Act of 1765 and to celebrate its repeal a year later. As conflict with the British government grew increasingly heated, the erection of the pole and cap became a widely recognised sign of rebellion, acting as a unifying banner for the revolutionary movement (Newman 1997, 24ff). This new banner was famously commemorated in a medal designed by Benjamin Franklin and minted in 1781 to commemorate the Declaration of Independence, five years earlier. The medal depicts the flowing haired profile of Liberty beneath the legend LIBERTAS AMERICANA. Behind her, as if thrown across her shoulder, are the pole and cap of liberty (Figure 4; Fischer $2005,137 \mathrm{ff})$.

The combination of the cap and the pole, thereby making the cap into a kind of battle standard, is quintessentially American, though it did have precedents in earlier European symbolism. ${ }^{7}$ It allowed the hat to become something new; no longer simply a political symbol employed in the representative arts, but a living and present badge borne in real time, about which individuals might rally and with which men might mark themselves out as members of a shared ideology. The symbol had circulated widely enough to enter the popular imagination.

The widespread use of the cap during the American Revolution thus served to give it an international capital as a symbol of Republicanism. Like the swastika one hundred and fifty years later, the liberty cap was lifted out of the field of antiquarian symbolism and given a new meaning, inseparable from the political position that it was used to represent. When Republican revolution thus swept through France, less than two decades after the declaration of independence, it was a natural symbol for the French rebels to drawn upon. On $15^{\text {th }}$ April 1792, when the Festival of Liberty paraded through Paris to honour Swiss soldiers who had rebelled against their officers in August 1790, 
both the Swiss soldiers and the French sans-culottes wore the bonnet rouge (as the cap is known in French). Apparently spontaneously, a member of the crowd also crowned a statue of the king with the cap, a pantomime which was made reality when, on $20^{\text {th }}$ June that same year, an armed mob invaded the royal apartments in the Tuileries and forced Louis XVI to don the red cap. Almost the first decision of the National Convention, in Sept 1792, long before they tackled the problem of what to do with their crownless king, was to adopt the bonnet rouge, borne aloft on a pike carried by Liberty herself, as the symbol of the new Republic (Harris 1981, 283-312; Benzaken 1998, 149-66).

Though certainly not representative of an ideology as repugnant as Nazism, the parallel with the swastika is apt. Like the swastika, the cap became in Paris a badge of loyalty, such that even those who felt no sympathy for the revolutionary cause found themselves compelled by social convention into wearing the bonnet rouge for fear, otherwise, of being branded a traitor (Harris 1981, 285-6). Overseas, stories of the Revolution's bloody excesses meant that any such revolutionary symbols came to be looked upon with considerable alarm and to be deployed in increasingly militant ways. In Britain the cap came to be used as a rallying symbol for radicals and appears to have reached the height of its popularity in the critical year 1819, the year of the Peterloo Massacre, where its appearance was taken as a sign that the mob would stop at no less than their own French Revolution (Epstein 1989, 75-118, at 79). In a period of enormous political tension, therefore, the cap came to embody a popular republicanism and to be associated in the minds of conservatives with the bloodiest excesses of revolution and so-called progress. ${ }^{8}$

\section{Naming a Mushroom}


All this brings us to the mushroom. In 1803, a little volume of poems, entitled Norbury Park, a poem; with several others written on several occasions, was published by Watts and Bridgewater of London. The author of these poems was one James Woodhouse (1735-1820), an ill-educated shoe-maker turned poet, who possessed a love of nature and a natural talent for verse sufficient to attract the patronage of William Shenstone and the disapprobation of Dr Johnson (Baines et al. 2011; Tierney 1988, 443, n. 1). Woodhouse's career was not without success, particularly given his low birth, and he ended his days as a bookseller in London with several published volumes of his own poetry to his name (Baines et al. 2011). The final poem of Norbury Park, entitled 'Autumn and the Redbreast, an Ode,' had been written by Woodhouse in 1787. In it, we find an extend paean to the beauty of the varied mushroom, lasting many lines, and whose central section I quote below:

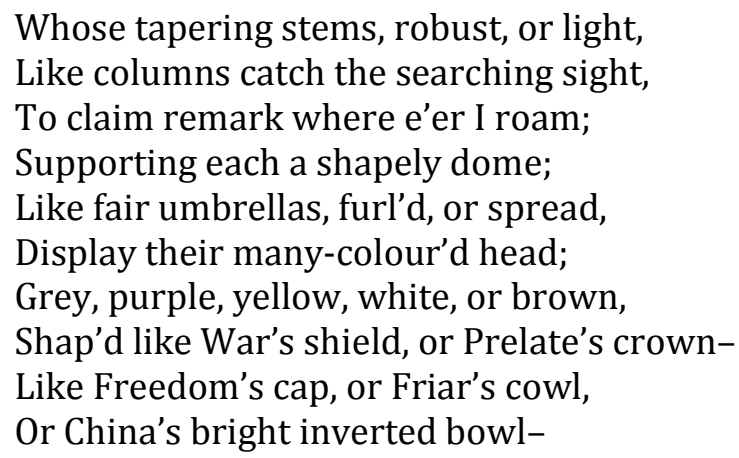

(Woodhouse 1803, 122-3)

Writing only four years after the end of the American Revolutionary War, and two before the storming of the Bastille, Woodhouse clearly had the liberty cap much on his mind as he took his autumn strolls, struck by how the little brown mushrooms rising up from the grass resembled the liberty cap upon the pole that had been the standard 
raised against the British soldiers during the American Revolution. Woodhouse clearly expected his audience to understand the reference attesting to the extent to which, as it had been for Petronius, the liberty cap had again become a current and present symbol whose relevance people were expected at once to recognise.

Such a passing metaphor in so minor a poet was hardly likely to make waves within the English language. In 1812, however, nine years after 'Autumn' appeared in print, two far more notable personalities, the poets Robert Southey and Samuel Taylor Coleridge, brought out their two volume collection of cultural, religious, and historical miscellany, entitled Omniana, or Horae Otiosiores. Initially published anonymously, the book covered a baffling range of subjects, from attacks on Catholic traditions to notes on early English metre. Amongst the objects of its consideration was the 'Cap of Liberty,' of which Coleridge wrote that '... there is a common fungus, which so exactly represents the pole and cap of liberty, that it seems offered by nature herself as the appropriate emblem of Gallic republicanism,- mushroom patriots, with a mushroom cap of liberty' (Omniana, nr. 111, 217). ${ }^{9}$ The 'mushroom patriots,' a contemporary term used to indicate men of no particular conviction who sprang up in the cause of patriotism only when conditions were favourable, helped to lend extra punch to this little aside.

Southey and Coleridge both were famous plagiarists and we know for a fact that they were acquainted with Woodhouse and his work. Southey, indeed, had actually reviewed Norbury Park in 1804 for the Annual Review and History of Literature, for 1803 (Southey 1804, 558). Furthermore, in the brief biography of Woodhouse that he published in 1831, Southey even quoted the very passage in which Woodhouse gives his ode to the mushroom (Southey 1831, 114-21, at 119-20). It seems plausible, therefore, to say that to Woodhouse is owed the credit for inventing this metaphor. Southey and Coleridge must have subsumed it and then, at some time during the composition of 
Omniana, which was pulled together from a hodgepodge of the pair's notebooks and conversations, Coleridge penned it as his own.

Had Coleridge not taken his 'mushroom cap of liberty' from Woodhouse, however, it is unlikely the term would ever have been propelled into more general usage. Southey and Coleridge were famous conduits for, and occasionally the genitors of, folklore and legend (Dorson 2001, I, 91ff). Omniana itself was widely read and its publication was also, coincidentally, well timed to capture the popular imagination, coming shortly before the political unrest that followed the Napoleonic War in which the liberty cap was much in evidence and much feared. Furthermore, Omniana went on to several reprints thanks to its later incorporation into a collection of Coleridge's work put together by his nephew, Henry Nelson Coleridge, and published in 1836 under the title The table talk and Omniana of Samuel Taylor Coleridge. ${ }^{10}$ In 1884, further additions from Coleridge's notebooks and marginalia were made by Thomas Ashe, and Omniana was published yet again, this time by G. Bell \& Sons of London. This volume was evidently well received; its second edition was printed in 1888, its third in $1896 .{ }^{11}$ Thus the 'mushroom cap of liberty' was, during the nineteenth century, circulated to a wide audience. Long after the cap itself had ceased to have any relevance in the world of popular political discourse, it was kept before the eyes of lettered men in much the way that Churchillian nostalgia keeps the ' $V$ ' of victory in our imaginations today.

The mushroom that Woodhouse and Coleridge would seem to have had in mind was Psilocybe semilanceata, which had been first formally identified as Agaricus semilanceatus by the great Swedish mycologist Elias Fries in his 1818 treatise Observationes mycologicae (Fries 1818, II, 178). Later in the century, the German Paul Kummer revised the genus Agaricus, into which Fries had placed all gilled mushrooms, raising many subgenera to the status of genera in their own right. Agaricus 
semilanceatus was thus reclassified as Psilocybe semilanceata, the name it retains today (Kummer 1871, 71). By the time mycologists began to include common names alongside their scientific appellations, it seems that Coleridge's 'mushroom cap of liberty' had penetrated the collective imagination sufficiently that the name 'Liberty Cap' was immediately in evidence, and always in reference to Psilocybe semilanceata. Perhaps its first such usage was in Mordecai Cooke's 1871 Handbook of the British Fungi (Cooke 1871, 148). Cooke was himself deeply interested in folklore and, indeed, in intoxicating plants, having produced, in 1860, a history of plant narcotics entitled The Seven Sisters of Sleep (Jay 2000, 195-6; Letcher 2006, 63-7). In 1894, between the second and third reprints of the Ashe edition of the Omniana, Cooke published his Edible and Poisonous Mushrooms, which tellingly refers to Psilocybe semilanceata, within quotation marks, as 'the "cap of liberty," ' exactly the phrasing used by Coleridge, whom it would appear that Cooke was consciously quoting (Cooke 1894, 89).

By the early twentieth century, textbooks, field guides, and proceedings of mycological societies routinely included common names and the Liberty Cap thus became concreted as the name of a tiny, unremarkable mushroom that few but dedicated specialists would ever have cause to notice. ${ }^{12}$ The symbol of popular revolt had become a scientific curiosity and would have so remained, were it not for the momentous discovery, in 1955, that long-doubted legends surrounding the Aztecs were true; growing in the mountains of Mexico, there existed vision-inducing mushrooms that brought about altered states of consciousness. This discovery was made by the most unlikely of subjects, one Robert Gordon Wasson, who had developed an obsession with mushrooms and their history several decades before. ${ }^{13}$ Wasson himself travelled to Mexico and sampled the mushrooms in a secret religious ceremony; he wrote up his experiences in a photographic article published in Time in $1957 .{ }^{14}$ The discovery was a 
revelation for both scientists and psychonauts alike, and attracted enormous attention. Samples sent by Wasson and others were analysed and it was soon discovered that many of the mushrooms belonged to the genus Psilocybe (Singer and Smith 1958, 262303). In 1958, a team led by the Swiss chemist Albert Hofmann, the man who first synthesised (and ingested) LSD, was able to isolate the main psychoactive compound in the mushrooms, which they named psilocybin (Hofmann et al. 1958 and 1959). In 1969, it was established in an article in the journal Transactions of the British Mycological Society that none other than the innocuous little British-growing Liberty Cap contained large quantities of the newly identified chemical (Mantle and Waight 1969, 302-4).

The import of the fact that so powerful a hallucinogen was growing freely on British pastures, uplands, even front lawns, was slow to filter to the growing psychedelic underground in Britain. Throughout the 1960s, occasional articles on mushroom tripping appeared in numerous publications, including the Sunday Telegraph (Letcher 2006, 227-9). Robert Graves sang the praises of hallucinogenic mushrooms and included his (groundless) musings on the ancient mushroom cults of Europe in the paperback editions of The Greek Myths (1960) and The White Goddess (1961) (Letcher 2006, 233-7). But the first documented mushroom trip in Britain does not appear to have taken place until 1970 (Darnton 1970). The real genesis of a flourishing mushroom culture in Britain was to occur in 1976, when the New Scientist reported on a UK court's landmark decision that an individual could not be prosecuted for possession of mushrooms (the judge stated that 'psilocin is a chemical and mushrooms are not'). The New Scientistarticle bore the headline 'Will the legal Liberty Cap mushrooms cause Home Office hallucinations?' The article included helpful illustrations of the Liberty Cap, indications of where it grew, and suggestions of what a typical dosage consisted (Carter 1976, 599). 
The creation of this legal loophole in Britain was followed quickly by the proliferation of field guides for the would-be picker, which served to further promote the fame of the Liberty Cap. A number of such guides were published in America from the late 60s onwards, the most famous of which, Magic Mushrooms of the Pacific Northwest, has sold over 100,000 copies since its first publication in 1976. In Britain, the most important such guide was Richard Cooper's A Guide to British Psilocybin Mushrooms, first published in 1977 in the immediate aftermath of the 1976 court ruling and the creation of mushrooms' legal loophole. Cooper's guide has been reprinted three times since this date, in 1979, 1980, and 1997, a testament to its popularity (Cooper 1977). The cover of the book features a colour drawing of Liberty Caps growing amongst long grass and, within, the Liberty Cap is the only mushroom to be given colour photographs, with four pages of images showing perhaps one hundred mushrooms in total. Today, the internet multiplies the opportunities for mushroom enthusiasts to share resources, and entire online fora are devoted to providing discussion space for 'shroomers.' Novice pickers use these spaces to present photos of mushrooms they have picked in order to confirm their identification. The recurrent question in such ID requests is, 'Are these libs?'15

Awareness of the Liberty Cap thus began gradually to filter into the public sphere during the 70s. Free festivals - music festivals at which drugs, including Liberty Cap mushrooms, were sold openly - became a regular fixture of the summer season, until they were eventually made illegal by Thatcher's government. Perhaps the largest such, the tenth Stonehenge Free Festival, held around the summer solstice of 1984, attracted 30,000 hippies and self-professed 'freaks' for a blending of music, psychedelia, and Neopaganism, for which the Liberty Cap had quickly become a conspicuous symbol. The poster for the festival included John Tenniel's drawing of the hookah smoking 
caterpillar from Alice in Wonderland in which the mushrooms in the foreground, which look remarkably like Liberty Caps, had been helpfully labelled 'magic mushrooms' by whoever put the poster together. Recognition of the Liberty Cap, in its new incarnation as a psychedelic gateway, saw it become a cipher, its distinctive shape included on clothing, in jewellery, in sculpture and artwork as shorthand for a psychedelic counterculture.

Although they were made a class A drug in Britain in 2005, the association between magic mushrooms - Liberty Caps in particular - and the UK festival scene has proven to be an enormously enduring one. Enormous, wood carved Liberty Caps are a staple installation at many festivals (see Figure 5). The Home Office estimates that $7.2 \%$ of adults in England and Wales, some 2.5 million people, have taken magic mushrooms in their lifetime and at the height of magic mushrooms' popularity in the UK, before they were finally made illegal, the Camden Mushroom Company alone was selling $100 \mathrm{kgs}$ approximately 25,000 'hits' - of magic mushrooms per week. ('Drug Misuse: Findings from the 2012 to 2013 Crime Survey for England and Wales' (25 July 2013), 1.8; Letcher 2006, 284). Whilst these retailed mushrooms were all non-native species, grown indoors, the Liberty Cap nevertheless retained a claim to the popular imagination both because of its distinctive appearance and because of the fact that it is the only mushroom containing significant amounts of psilocybin that will grow on British soil.

\section{Conclusion}

From a knowing cultural reference of Victorian gentleman scholars, the Liberty Cap thus became a secret badge for drug using cognoscenti, bent on 'liberating' their 
consciousness. As Andy Letcher puts it, in his 2006 book, Shroom, '[the Liberty Cap] proclaimed that those who knew and used the mushroom were an elect pagan few, pitted against the rising tide of consumerism and, like the mushrooms themselves, living on the margins' (Letcher 2006, 249). Today, therefore, beside a small community of scholars who may know of the liberty cap for its political significance in their own era of expertise, the vast body of people who know the term know it as the street name of a powerful hallucinogen. The pages of erowid.org, shroomery.org, lycaeum.org, and other online fora dedicated to allowing drug users to share their experiences and advice with one another are piled high with accounts of the mental or spiritual 'liberation' that the Liberty Cap has afforded. ${ }^{16}$ The language of these discussions, dependant as it is open a modern psychedelic discourse, was of course not available to Roman slaves. Yet what is striking about it is that, unbeknownst to those who use it, the language of personal liberation was, more than two thousand years ago, how the liberty cap symbol first began its journey, as the pileus of the freed slave. Modern, grassroots organisations, like The Shroom Liberation Front, which declare the Liberty Cap 'a mushroom that symbolises the essence of freedom itself,' unknowingly evoke, through the cultural prism of modern psychedelic liberation, a play of words and symbols that has been, in various guises, going on since the Roman Republic. ${ }^{17}$ Indeed, so firmly rooted is the modern context of the quasi-religious significance of the mushroom that the more determined (and, perhaps, beshroomed) conspiracy theorists even declare that the appearance of the pileus in ancient art is evidence of an encoded magic mushroom cult that has endured in a continuum from the prehistoric past. ${ }^{18}$

At each stage in a long and sometimes unlikely journey, the liberty cap symbol has been reinvented for new contexts - popular or elite, physical or allegorical - and so has taken on new meaning. Chance, theft, and the interplay of elite and popular symbolism 
preserved an idea that might otherwise have died long ago when the context that

birthed it - Roman slavery - ceased to exist. And despite all the sweat, toil, and

creativity that brought this term to the twenty first century, it is an accident of biology -

the presence of psilocybin in an obscure little mushroom - that means that today,

thousands of people are clandestinely searching the fields and hillsides of Europe on

wet autumn days, hoping to find a cap of liberty that could land them in jail.

Author biography: Adrastos Omissi is a British Academy Postdoctoral Fellow in the Faculty of History, University of Oxford, and a Junior Research Fellow in Classics and Ancient History at Oriel College, University of Oxford. He specialises in the civil wars of the later Roman Empire.

\section{Notes}

${ }^{1}$ I would like to Dr Sarah Watkinson, Anne Catterall, Geoffrey Kibby, Dr Martyn Ainsworth, and Prof Tim Fulford for guidance on aspects of mycology. My thanks also to Andy Letcher and, in particular, Mike Jay for help and advice on the culture and history Psilocybe semilanceata and its use in Britain.

${ }^{2}$ See for instance: Wakefield and Dennis 1950, 199; Weil 1980, 77; Wilson 1999, 30-2; Colman 2009, 421-2; Letcher 2006, 14; Ruck, Hoffman, and Celdrán 2011, 59. It is erroneously claimed (Watling 2007, 403-6), that the name is derived from the resemblance of the mushroom to French helmets during WWI; as this article will show, this is impossible as the name predates WWI by nearly 130 years.

${ }^{3}$ Ironically enough, pileusis the modern scientific term for the head or cap of all mushrooms: Moore-Landecker 1972, 560.

${ }^{4}$ Numerous emperors also employed the pileus on their coins as a symbol of freedom from tyranny, e.g. Kragelund 1982, 43.

5 The Iconologia was hugely popular. There were nine Italian editions $(1593,1603,1611,1613,1618,1625,1630,1645$, and 17647) and eight non Italian editions in other languages: French (1644 and 1766), Dutch (1644 and 1699), German (1704 and 1760), and English (1709 and 1779), many of which were reprinted multiple times: Zimmermann 1995, 17-25.

${ }^{6}$ For the adoption of this symbol in the Netherlands, see Nyquist, Arbitrary Rule, 156-61. The shape of the liberty cap was clearly not known in this period - Cesare Ripa's cap is also wide brimmed, whilst Alciatus' illustration was actually a reproduction of the coin struck by Brutus in $44 \mathrm{BC}$.

${ }^{7}$ The coin of William of Orange, mentioned above, depicted the liberty cap atop a column, and Hogarth's print likewise showed Wilkes with the cap upon a pole. Likewise, the Roman writer Appian (Bellum Civile, 2.119.1) suggests that the anti-Caesarean conspirators may have born a pileus upon a spear through the streets of Rome.

${ }^{8}$ This is not to say that the cap was utterly reviled in Britain. It continued to appear frequently both as an image and in text (see for instance Griffin 2002, 285).

${ }^{9}$ My thanks to Mike Jay, who alerted me to this work, which allowed me to bridge the gap between Woodhouse and the mycological texts.

${ }^{10}$ This was included among the Literary Remains collection: Cheshire 2009, 296. Southey was confident it would sell well and expressed this in a letter to John Rickman, dated 21st Jan. 1810; cf. Packer and Pratt 2013, nr. 1734.

${ }^{11}$ It went on to numerous reprintings in the twentieth century as well.

${ }^{12}$ E.g. Hay 1887, 171; Massee and Crossland 1905, 108; New York State Museum Annual Report62:2 (1908), Appendix 5, 37; Morey 1909, 51; New York State Museum Annual Report65:2 (1911), Appendix 4, 103; Proceedings - Dorset Natural History and Archaeological Society 35 (1914), 177; Pegler 1966, 219; Weil, 1977, 131-48.

${ }^{13}$ His major works on the topic Wasson and Wasson 1957 and Wasson 1968.

${ }^{14}$ For a summary of mushroom use in Aztec history: Schultes and Hofmann 1979, 145ff. For the article detailing the 1955 discovery: Wasson 1957. Letcher 2006 is vital reading for a counter-narrative on Wasson's discovery.

${ }^{15}$ E.g. https://mycotopia.net/topic/71811-are-these-libs/; http://www.shroomery.org/forums/showflat.php/Number/15317645; http://www.shroomery.org/forums/showflat.php/Number/20040505;

http://www.shroomery.org/forums/showflat.php/Number/15128476;

http://www.shroomery.org/forums/showflat.php/Number/20765680; and https://mycotopia.net/topic/51736-some-libs/ (all retrieved 11th Feb 2015). 
${ }^{16}$ E.g. http://www.bluelight.org/vb/threads/346073-Mushrooms-First-time-25-caps;

http://www.shroomery.org/forums/showflat.php/Number/11369015; http://www.tribalwar.com/forums/archive/t670433.html; http://www.cracked.com/funny-4202-shrooms/ (all retrieved 11 1 th $^{\text {Feb } 2015) .}$

${ }^{17} \mathrm{http}: / /$ shroomliberationfront.com/index.php and https://www.youtube.com/watch?v=EzljFySvmRU (retrieved 11 ${ }^{\text {th }}$ Feb 2015).

${ }^{18}$ Jake Kotze, 'The Phrygian Liberty Cap and the Magic Mushroom': http://mushroom-atlantis.blogspot.co.uk/2006/09/phrygian-

liberty-cap-and-magic.html (retrieved $11^{\text {th }}$ Feb 2015).

\section{References Cited}

Alciatus, Andrea. Emblemata [Emblems]. Venica, Aldus, 1546.

Allen, John W. Magic Mushrooms of the Pacific Northwest. Psilly Publiching 1976.

Benzaken, John-Charles. 'De l'effigie de Louis XVI à celle de la République: Iconographie numismatique du passage de la monarchie constitutionnelle à la République (août 1792-avril 1793)' [From the effigy of Louis XVI to that of the Republic: Numismatic iconography of the passage from constitutional monarchy to the Republic (August 1792-April 1793)]. In Symbols, Myths and Images of the French Revolution: Essays in Honour of James A. Leith, edited by Ian Germani and Robin J. W. Swales, 149-66. Regina: University of Regina Press, 1998.

Buckland, William W. The Roman Law of Slavery: the condition of the slave in private law from Augustus to Justinian. Cambridge: Cambridge University Press, 1908.

Carter, Michael. 'Will legal Liberty Cap mushrooms cause Home Office Hallucinations?'. New Scientist, 16 Sept 1976, 599.

Colman, Andrew M. A Dictionary of Psychology. $4^{\text {th }}$ ed. Oxford: Oxford University Press, 2009.

Cooke, Mordecai C. Handbook of the British Fungi. London: MacMillan and co., 1871.

-_- Edible and Poisonous Mushrooms: What to Eat and What to Avoid. London: Society for Promoting Christian Knowledge, 1894.

Cooper, Richard. A Guide to British Psilocybin Mushrooms. Red Shift Research Collective, 1977.

-_- A Guide to British Psilocybin Mushrooms. London: Hassle Free Press, 1979, rev. edn.

-_- A Guide to British Psilocybin Mushrooms. London: Hassle Free Press, 1980 2nd edn.

-_—. A Guide to British Psilocybin Mushrooms. London: Hassle Free Press, 1994.

-—- A Guide to British Psilocybin Mushrooms. Knockabout Comics; $2^{\text {nd }}$ Revised edition 1997.

Cheshire, Paul. 'Coleridge's Notebooks'. In The Oxford Handbook of Samuel Taylor Coleridge, edited by Frederick Burwick, 288-306. Oxford: Oxford University Press, 2009.

Crawford, Michael. Roman Republican Coinage. Cambridge: Cambridge University Press, 2001.

Darnton, Lynn. 'Magick Mushroom'. Oz 31, Nov/Dec 1970.

UK Home Office. 'Drug Misuse: Findings from the 2012 to 2013 Crime Survey for England and Wales'. 25 July 2013. Home Office Report, available at: https://www.gov.uk/government/publications/drug-misuse-findings-from-the2012-to-2013-csew/drug-misuse-findings-from-the-2012-to-2013-crime-survey-forengland-and-wales.

Dorson, Richard M. History of British Folklore. London: Routledge, 2001. 
Edmondson, Jonathan C. 'Public Dress and Social Control in Late Republican and Early Imperial Rome'. In Roman Dress and the Fabrics of Roman Culture, edited by Jonathan C. Edmondson and Alison Keith, 21-46. Toronto: University of Toronto Press, 2008.

Epstein, James. 'Understanding the Cap of Liberty: Symbolic Practice and Social Conflict in Early Nineteenth-Century England'. Past and Present 122 (1989): 75-118.

Fischer, David H. Liberty and Freedom: A Visual History of America's Founding Ideals. Oxford: Oxford University Press, 2005.

Fries, Elias M. Observationes mycolologicae [Mycological observations]. Havniae, 1818. Griffin, Dustin. Patriotism and Poetry in Eighteenth-Century Britain. Cambridge: Cambridge University Press, 2002.

Haard, R., and K. Haard. Poisonous and Hallucinogenic Mushrooms. Cornell: Cloudburst, 1975.

Harden, J. David. 'Liberty Caps and Liberty Trees'. Past \& Present 146:1 (1995): 66-102.

Harris, Jennifer. 'The Red Cap of Liberty: A Study of Dress Worn by French Revolutionary Partisans 1789-94'. Eighteenth Century Studies 14:3 (1981): 283-312.

Hay, William D. An Elementary Text Book of British Fungi. London: Swan Sonnenschein, 1887.

Higham, John. Hanging Together: Unity and Diversity in American Culture. New Haven, Conn.: Yale University Press, 2011.

Hofmann, A., R. Heim, A. Brack, and H. Kobel. 'Psilocybin, ein psychotroper Wirkstoff aus dem mexikanischen Rauschpilz Psilocybe mexicana Heim' [Psilocybin, a psychotropic agent from the Mexican hallucinogenic fungus Psilocybe mexicana Heim]. Experientia 14:3 (1958): 107-9.

Hofmann, A., R. Heim, A. Brack, H. Kobel, A. Frey, H. Ott, T. Petrzilka, and F. Troxler. 'Psilocybin und Psilocin, zwei psychotrope Wirkstoffe aus mexikanischen Rauschpilzen' [Psilocybin and Psilocin, two psychotropic agents from Mexican hallucinogenic fungi]. Helvetica Chimica Acta 42:5 (1959): 1557-72.

Holman, Beth L. 'Goltzius' Great Hercules: mythology, art and polities'. Nederlands Kunsthistorisch Jaarboek 42:1 (1991): 397-412.

Jay, Mike. Emperors of Dreams: Drugs in the Nineteenth Century. Sawtry, Cambs.: Dedalus, 2000.

Kotze, Jake. 'The Phrygian Liberty Cap and the Magic Mushroom'. http://mushroomatlantis.blogspot.co.uk/2006/09/phrygian-liberty-cap-and-magic.html (retrieved $11^{\text {th }}$ Feb 2015).

Kragelund, Patrick. Prophecy, Populism, and Propaganda in the 'Octavia'. Copenhagen: Museum Tusculanum, 1982.

Kummer, Paul. Der Führer in die Pilzkunde: Anleitung zum methodischen, leichten und sichern Bestimmen der in Deutschland vorkommenden Pilze: mit Ausnahme der Schimmel- und allzu winzigen Schleim- und Kern-Pilzchen The mycological guide: Instructions for methodical, easy, and secure identification of fungi occurring in Germany: With the exception of moulds and small myxomyces and pyrenomyces]. Zerbst: E. Luppe, 1871.

Letcher, Andy. Shroom: A Cultural History of the Magic Mushroom. London: Faber and Faber, 2006.

New York State Museum Annual Report 62:2 (1908) and 65:2 (1911).

Newman, Simon P. Parades and the Politics of the Street: Festive Culture in the Early American Republic. Philadelphia: University of Pennsylvania Press, 1997. 
Nyquist, Mary. Arbitrary Rule: Slavery, Tyranny, and the Power of Life and Death. Chicago and London: University of Chicago Press, 2013.

Maier, Pauline. 'John Wilkes and American Disillusionment with Britain'. The William and Mary Quarterly 20:3 (1963): 373-95.

Mantle, P. G., and E. S. Waight. 'Occurrence of psilocybin in sporophores of Psilocybe semilanceata'. Transactions of the British Mycological Society53:2 (1963): 302-304.

Massee, G., and C. Crossland. The Fungus Flora of Yorkshire: A complete account of the known fungi of the county. London: A. Brown \& Sons, 1905.

Miller, Richard J. Drugged: The Science and Culture Behind Psychotropic Drugs. Oxford: Oxford University Press, 2014.

Moore-Landecker, Elizabeth. Fundamentals of the Fungi. New Jersey: Prentice Hall, 1972.

Morey, Frank, ed., A Guide to the natural history of the Isle of Wight: a series of contributions by specialist relating to the various branches of Natural History and kindred subjects. Isle of Wight: The Country Press, 1909.

Omniana: or Horae Otiosiores [Miscellany: or Leisure Hours]. London, 1812.

Packer, I., and L. Pratt, eds. The Collected Letters of Robert Southey. Part 4, 1810-1815. Romantic Circles electronic edition, 2013.

Pegler, David N. 'Additions to the Wild Fauna and Flora of the Royal Botanic Gardens, Kew: XXXVII. A Revised List of the Agarics and Boleti'. Kew Bulletin of Miscellaneous Information 20 (1966): 201-231.

Proceedings - Dorset Natural History and Archaeological Society 35 (1914).

Ramsay, William. 'Saturnalia'. In A Dictionary of Greek and Roman Antiquities, edited by William Smith. London: Murray, 1875.

Ripa, Cesare. Iconologia overo Descrittione dell' imagini universali cavate dall' antichità e da altri luoghi [Iconography or rather description of universal images mined from ancient sources and other places]. Roma: 1603.

Ruck, C. A. P., M. A. Hoffman, and J. A. G. Celdrán. Mushrooms, Myth and Mithras: The Drug Cult that Civilised Europe. San Francisco, CA: City Lights, 2011.

Schultes, R. E., and A. Hofmann. Plants of the Gods: Origins of Hallucinogenic Use. London: Hutchinson, 1979.

Singer, R., and A. H. Smith. 'Mycological investigations on Teonanácatl, the Mexican Hallucinogenic mushrooms part two: A taxonomic monograph of Psilocybe section Caerulescens'. Mycologia 50:2 (1958): 262-303.

Southey, Robert. The lives and works of the uneducated poets. London: John Murray, 1831.

- - - Review of 'Norbury Park, a Poem; with several others: written on various Occasions. By James Woodhouse'. In Annual Review, and History of Literature 2 (1804): 558.

Stamets, Paul. Psilocybin Mushrooms of the World: An Identification Guide. Berkeley: Ten Speed Press, 1996.

Tang, Sam. From Slaves to Sons: A New Rhetoric Analysis on Paul's Slave Metaphors in His Letter to the Galatians. Oxford: P. Lang, 2005.

Tierney, James E., ed. The Correspondence of Robert Dodsley 1733-1764. Cambridge: Cambridge University Press, 1988.

Wakefield, E. M., and R. W. G. Dennis. Common British Fungi: A guide to the more common larger Basidiomycetes of the British Isles. London: P. R. Gawthorn, 1950.

Wasson, Robert G. Soma: Divine Mushroom of Immortality. New York: Harcourt, 1968.

_——. 'Seeking the magic mushroom'. Life 42:19 (1957): 100-2, 109-20. 
Wasson, R. G., and V. P. Wasson. Mushrooms, Russia, and History. New York: Pantheon, 1957.

Watling, Roy. 'Psilocybe semilanceata - a hallucinogenic mushroom native to Europe'. In Supernatural: Meetings with the Ancient Teachers of Mankind, edited by Graham Hancock, 403-6. New York: Disinformation, 2007.

Weil, Andrew T. 'The Use of Psychoactive Mushrooms in the Pacific Northwest: an Ethnopharmalogic Report'. Botanical Museum Leaflets, Harvard University 25:5 (1977): 131-48.

-_- The Marriage of the Sun and Moon: Dispatches from the Frontiers of Consciousness. Boston, Ma.: Houghton Mifflin, 1980.

Wilson, Peter L. Ploughing the Clouds: The Search for Irish Soma. San Francisco, CA: City Lights, 1999.

Woodhouse, James. Norbury Park, a poem; with several others written on several occasions. London: Watts and Bridgewater, 1803.

'Woodhouse, James'. in The Wiley-Blackwell Encyclopaedia of Eighteenth-Century Writers and Writing, edited by Paul Baines, Julian Farraro, and Pat Rogers (Oxford: Wiley-Blackwell, 2011).

Yates, James. 'Pileus'. In A Dictionary of Greek and Roman Antiquities, edited by William Smith, 919-21. London: Murray, 1875.

Zimmermann, Hans-Joachim. 'English Translations and Adaptations of Cesare Ripa's Iconologia: From the 17th to the 19th Century'. De zeventiende eeuw. Jaargang 11 (1995): 17-25.

\section{Captions to Figures}

Figure 1: Psilocybe semilanceata, the Liberty Cap. Source: wikicommons.

Figure 2: The EID MAR coin, minted by Brutus after the murder of Caesar in $44 \mathrm{BC}$ and showing the pileus between a pair of daggers (cf. Crawford 2001, 508/3). Source: wikicommons.

Figure 3: William Hogarth's 1763 satirical image of John Wilkes, with the pole-and-cap of liberty over his shoulder. Source: wikicommons.

Figure 4: The LIBERTAS AMERICANA medal of 1781, showing liberty with the distinctively American pole-and-cap. (C) Heritage Auctions. Reproduced by permission of Heritage Auctions.

Figure 5: Magic Mushroom sculptures at Glastonbury in 2007. (C) James Golding. Reproduced by permission of James Golding. 